\title{
Research on Training Vocational Abilities of Students in Colleges of Higher Vocational and Technical Education
}

\author{
Yihe Huang \\ Hainan Institute of Science and Technology, Haikou, China
}

\begin{abstract}
The article analyzes the composition, connotation and characteristics of vocational abilities starting from the definition of vocational abilities, discusses on the various problems influencing training of vocational abilities from the aspects of college features, role of enterprises and government overall consideration, and analyzes the reason for the difficulties in training of vocational abilities with reference to theories like industrial agglomeration theory. Finally, the article makes the conclusion that the higher vocational and technical education colleges shall improve training quality, efficacy and features to increase teaching level, enterprises shall have full range cooperation with the colleges on the basis of mutual benefits, and the government shall enhance overall regional consideration etc. The article is helpful for the higher vocational and technical education colleges to establish correct value of education, talent and quality, increase management level, quality and efficacy and improve competitiveness and adaptation of the colleges.
\end{abstract}

Keywords-Higher Vocational and Technical Education College; Abilities; Cooperation between Schools and Enterprises

\section{INTRODUCTION}

The rapid development of higher vocational and technical education colleges provides a historic opportunity for the training of vocational abilities. Higher vocational and technical education is an important part of higher education in China. In recent years, higher vocational and technical education has developed very fast. From 1998 to 2003, the average increase rate of students' enrollment number is $35.99 \%$, and the average growth rate of the number of undergraduate students is $32.47 \%$. There are 908 higher vocational and technical education colleges in China, 164 private ones. Since we are on the path of new industrialization with information driving industrialization and industrialization facilitating information, the industrial structure and employment structure may have or are having great changes in the sustainable development system of industrial society. There will be more and more demands for intellectual workers including high tech personnel. These urgently required talents mainly distribute in manufacturing and modern service industries and so on. These talents need to have good vocational abilities and they belong to high level technical talents. As higher vocational and technical education colleges are the main educational institution for such talents, the colleges shall take this opportunity to train students the vocational abilities to serve for economic development.
Among all educational systems, vocational education is most directly and closely related to national economic development. It shoulders the task of providing high level professional technical talents for the national economic development. The international labor organization points out in World Employment Report (1998-1999): “a country's economic construction mainly depends on the acquisition and application of new technology and working skills". Nowadays, our economy keeps on developing rapidly; it is urgently required for us to train a large amount of high level practical talents for economic construction.

The higher vocational and technical education colleges put more emphasis on "application" in their training target. On the basis of moral, intellectual, physical and artistic development and basic theoretical and specialized knowledge, the students are required to have basic ability and skills for practical work at a post to meet requirements of local industrial economic development and duty post or duty post group. Therefore, the higher vocational and technical education colleges take training and improvement of competence as the core of quality education. The training of vocational ability is a specific important component of this core.

The essential task of vocational education is vocational skills education. Vocational skills are the guarantee for living for students to participate in the ever first job they get after graduation. To reach this goal, the key is to improve the skills of the workers and improve their working ability and adaptive ability to vocational changes. The reason why graduates from higher vocational and technical education colleges find difficulty in finding a job while there is actually shortage of high level technical talents is that the skills training in higher vocational and technical education colleges has not been efficient enough and students lack sound professional skills. They cannot meet the requirements of employing companies and thus are abandoned by the market. Therefore, to thoroughly change such a situation, the higher vocational and technical education colleges have to set up a vocational education system guided by employment urgently and take feasible and effective measures to enhance training of vocational skills to ensure each student has the competence to win competition.

For a long time, the higher vocational and technical education colleges in China do not have outstanding features. The training of vocational abilities usually emphasizes theory instead of practice. The students are weak in practical working ability and creativeness. The 
graduates cannot meet actual requirements of enterprises easily. The article, subject to problems like the enclosed teaching environment of these colleges, deviation from actual social production status, and weak modularization of courses etc. in the training of vocational abilities, proposes to take training of professional ability and key ability as the breakthrough point to prompt overall increase of the students' quality.

\section{CONNOTATION OF VOCATIONAL ABILITY OF STUDENTS IN HigHER VOCATIONAL AND TECHNICAL EDUCATION COLLEGES}

\section{A. Analysis of Vocational Ability.}

The American management expert Stephen P. Robbins views occupation from the view of management. He thinks that occupation is "the course of shouldering duty in one's life" [1]. The definition of occupation by sociology is that it is the integrated reflection of living style, economic status, cultural level, behavior model and ideology [2]. Ability is the qualification for a person to complete certain social practical work including necessary psychological characteristics and detailed methods. It is the external expression of one's knowledge, intelligence and quality, and is developed through learning and practice.
Currently the academia generally defines the connotation of vocational ability from the composition of vocational ability. It is viewed as the integration of various abilities. However, different scholars have different opinions on the composition of vocational ability. The following are some representative views:

Vocational ability consists of core, general and specific vocational abilities.

Vocational ability refers to the integrated vocational ability of knowledge, competence, quality and thinking for a job, including abilities of business, creativity and flexibility. [4]

Vocational ability consists of basic, professional and key abilities. It refers to the ability to take on a modern occupation and is the integrated external expression of knowledge, psychology, quality and skills. The vocational ability of students in higher vocational and technical education colleges consists of basic, professional and key abilities. [5]

Vocational ability consists of general and special vocational abilities.

Vocational ability is the requirement of qualification of the employees by the occupation. Vocational ability is the task and duty that certain specialty requires the corresponding occupational group to achieve and is the reflection of the integrated quality required for an occupation.

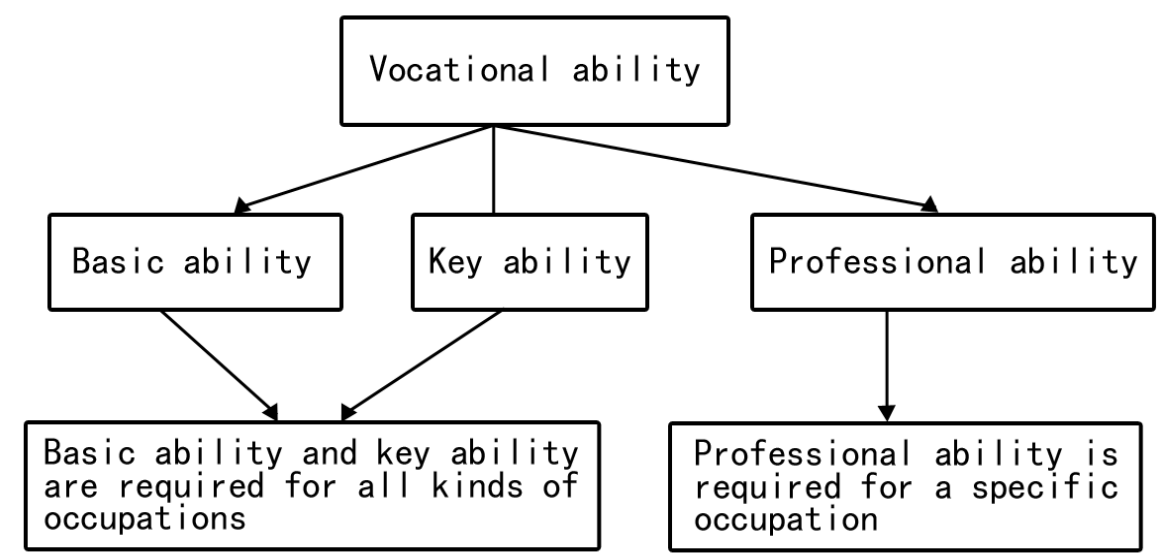

Figure 1. composition of vocational ability

Vocational ability includes 3 types of ability: basic ability, professional ability and key ability as shown in figure 1. Basic ability mainly includes basic reading, writing, calculation, language, judgment abilities. Professional ability mainly includes necessary professional knowledge, theory, skills, and quality for a certain post. Key ability mainly includes learning ability and social ability. The three abilities have clear classification of layers. Basic ability is the foundation of vocational ability, professional ability is the intermediate layer, and key ability is the highest layer of training. The higher the layer is, the more difficult the training is.

B. Factors Influencing the Training of Vocational Abilities to Higher Vocational and Technical Education Colleges' Students.

The vocational ability training shall satisfy needs of society and also students' individual needs. Therefore, we must ensure the balance between instrumentalism and humanism and between economic benefits and value. Meanwhile, the training shall follow market rules and educational rules. The training is a complicated systematic course with many influencing factors.

Conceptional factors include concept of education, view of talent, view of competence, self realization of students and related theories etc. Conceptional factors play a guiding role in the training of vocational ability.

Quality factors refers to the factors to guarantee operation and running of training including teaching staff, finance and equipment etc. and systematic factors like ability training model and evaluation system. Quality factors play a fundamental role in the training of vocational ability.

Special factors include locating features, specialty features, practice and teaching features, features of school-enterprise cooperation and evaluation system 
features etc. The special factors relate to the direction of needs of vocational abilities. Therefore, features are subject to the demands of market.

Management factors include students' management, teaching management, government overall consideration and level of innovation etc. The management factors show the control level on the training course of vocational ability.

\section{Operation System of Training of Vocational Ability to Higher Vocational and Technical Education Colleges' Students.}

The object of training of vocational ability is the higher vocational and technical education colleges' students. The training is realized through the cooperation between colleges, enterprises and the government. The detailed roles are different.

The colleges are the implementation institute for the training of the vocational ability. The colleges have the training responsibility. This is as per the task and duty of the higher vocational and technical education colleges.

Enterprises are the active participant in the course of the training and the cooperator of the colleges. Enterprises cooperate with colleges to train students by providing internship opportunities and alternation of study and work. Though the subjective purpose of cooperation with colleges is to realize maximum profits, the objective effect of such cooperation is it helps to improve the vocational ability of the students.

The government makes overall consideration during the training course of vocational ability and indirectly influences on the training. The overall consideration measures include provision of funds and preferential policy, instructions, coordination and arrangement for school-enterprise cooperation, and formulation of teaching schemes etc. The colleges and enterprises have the relation of equal cooperation and have mutual benefits on voluntary basis. The government plays the role of coordination and overall consideration.

\section{Development Tendency of Vocational Ability of Higher Vocational and Technical Colleges' Students.}

Vocational education pays more and more attention on individual development and the target of courses shifts from training on simply professional skills and special abilities to cultivation of comprehensive vocational ability. It tends more to the unification of instrumentalist value and development value. This tendency will inevitably prompt the organic integration of various courses. The goal of courses shifts from the simply skilled type training to integrated development with vocational ability as the core. The overall tendency is discipline-competence-personality tendency [7]. As the technical talents are usually the organizer and manager of a working group, key abilities like cooperation, communication, organization, coordination and risk bearing and so on and non-technical quality like good personality and professional ethics are very important. Therefore, the higher vocational and technical education colleges' students cannot be suitable for only limited posts but should be with strong flexibility and adaptation to employment.
Criteria for Defining the Content of Vocational Ability. The graduates from higher vocational and technical education colleges shall meet the requirements of companies for the corresponding posts, i.e. meet the requirements of criteria [8]:

Criteria that they shall adapt to changes of employment organization

Criteria that they shall adapt to changes of occupational structure

Criteria that they shall adapt to unpredicted changes of needs in the market

\section{CURRENT PRoblems IN Vocational AbiLITY TRAINING FOR THE HIGHER VOCATIONAL AND TECHNiCAL EDUCATION COLLEGES' STUdENTS}

Our higher vocational and technical education has obtained some experience on the training of vocational ability after 10 years rapid development and has got great achievement. However, generally it is still at the stage of continuous development and there are still many problems.

\section{A. Lack of scientific and overall view in the understanding of vocational ability.}

Vocational ability is the core target of vocational education. Previously, vocational ability was confused with skills. During the course of training and cultivation, attention was often given to the cultivation of a specific skill or practical operation method. But in the 21st century, the employees should not only have excellent operation skills but also other abilities like innovation, communication, organization and management, analysis and judgment, adaptation, competitiveness, psychological withstand ability and so on.

\section{B. Lack of attention from college leaders on the cultivation of vocational ability.}

The cultivation of integrated vocational ability is a complicated systematic project, which is influenced by internal factors and related external factors. For apparent reason, the current focus of the colleges is enrollment and employment. For a long time, employment has been regarded as the main target. The education task is viewed as enrollment of students and employment when they graduate. There has not been enough attention on whether they can work well at the post and on their future existence and development and lift long education and so on. The cultivation and improvement of vocational ability is neglected.

Weak ability for practical work of the higher vocational and technical education colleges' students

It shows in two aspects.

The solution efficiency of the known clarified working problems is low. Though the students know the solving principle of such problems, they cannot convert it into actual solution. This reflects that during the training and cultivation of vocational ability, more attention is given on theory and practice is neglected.

Solution cannot be found out for the obscure type working problems. The students fail to use their knowledge and experience to make effective analysis on the obscure problems and cannot find subjective solution 
scheme and method. It shows that there has not been enough exercise on knowledge transfer and application during the training and cultivation of vocational ability.

\section{Vocational Ability Targeting at Single Specific Post.}

The employees devote their vocational ability into the economic development, and the intellectual economy is more complicated which has higher demand of quality of employees. All kinds of knowledge are possible to be used at work. Therefore, the traditional training mode taking training for a specific post or duty cannot meet the current requirement of training for these colleges' students. The new cultivation mode is shifting toward training students for a group of work and these talents should have high level adaptation ability.

\section{Lack of System and Important Points in the Cultivation of Vocational Ability.}

The emergence of a large number of new occupations brings opportunities and also grave challenges to the workers. In the combination of basic ability, professional ability and key ability, obviously importance is given to some component and some other components have not got enough attention. Lots of attention is given to cultivation of professional ability, while basic ability and key ability are neglected. And in the cultivation of professional ability, too much attention is given to impartation of professional knowledge and professional theory, whole professional skills and professional quality are neglected. Impartation and heritage are given lots of attention, while application and innovation are ignored.

\section{StRategies to IMPROVE Vocational AbILITy of THE HIGHER VOCATIONAL AND TECHNICAL EDUCATION COLLEGES'STUDENTS}

Reform and innovation are the essential solution to the training of vocational ability to the higher vocational and technical education colleges' students. It shall be done in the fields of concept, quality features, management system etc. The updating of concept is the premise for solving the problem of vocational ability training, quality and features of the cultivation is the core, and innovation of management system is the essential method for solving the problem of vocational ability training.

The discussion above has clarified the important points in the work of colleges. From the figure, we can see that the cultivation of key ability is very different from that of professional ability. Key ability puts more focus on self directed learning and inspiration instead of impartation from teachers. The key ability can only be truly obtained through practice. Therefore, there are two strategies to improve the cultivation of key ability. One is that teachers enhance their role model function during the training to guide students to imitate, learn and apprehend; the other is to enhance the practicality of cultivation through methods like moral practice and work practice and so on. The cultivation of vocational ability to these colleges' students can be improved in means of locating features, changing educational concept, proper setting of specialties, establishment of teaching staff, design of teaching material, development of course module, moral practice and establishment of diversified evaluation system etc.

\section{A. To Enhance Construction of Features of the Colleges.}

The colleges shall set up featured specialties based on the actual conditions of the colleges as per the industrial structure and economic development status in the area and make changes and adjustment in time as per needs of market to make the layout of specialties more reasonable. To put it more detailed, it can be located from the following aspects:

\section{B. To Change the Teaching Concept of the Colleges.}

Competency based education has both advantages and disadvantages. Personality based education shall be realized by enhancing customer guidance. The educational, economic and social functions shall be unified. As per the concept of customer guidance, the educational functions shall be realized taking students as the customers, the economic functions taking enterprises as customers, and social functions taking society as the customer.

\section{To Set up Proper Specialties.}

Detailed method of setting up specialties is to cooperate with enterprises to set up specialties as per needs of society and market, and enhance feasibility research on occupation and specialty development. The development of specialties should follow internationalized idea and advanced vision. The specialties should be set up with combination of high tech.

\section{To Establish Double-qualified Teaching Staff.}

Pay attention to establish team of double-qualified teaching staff and select talents by various means. The teaching staff can come from the production line of enterprises, and young teachers can be sent to the enterprises to get practical experience. The engineering, technical and management personnel of enterprises can be hired as part time teachers, and some senior technicians with rich experience can be selected as supervising teachers.

\section{E. To Formulate Teaching Textbook and Materials Suitable for Vocational Development.}

We should formulate teaching textbook and materials suitable for vocational ability training to facilitate training.

\section{F. To Develop Modularized Courses.}

Modularized courses are formed by proper learning units selected as per specific purpose and needs of the learners. Each module consists of several learning units. A complete course module also includes training target, required material for learning, and auxiliary material for the learning of this section and evaluation standard and so on. 
G. To Carry out Practice of Professional Ethics.

We can facilitate the cultivation of vocational ability by means of cultivating students' occupational ideal, discipline and behavior etc. This moral practice method strengthens the understanding of vocational ability study and the motivation for study by stimulating internal sense of responsibility within the students so that the goal of improving innovation and psychological bearing capability can be reached.

\section{H. To set up Diversified Evaluation System for Education Quality.}

We shall have innovation in the evaluation system for education quality and method. We shall change the traditional formation evaluation to be evaluation on development, and change the traditional finalized evaluation to be evaluation on process. We shall also shift emulation evaluation to be evaluation on real situation, and change internal evaluation to be combination of internal and external evaluation.

\section{CONCLUSION}

The rapid development of higher vocational and technical education will help greatly to improve the quality of workers and satisfy the diversified needs of economic development for talents. The above analysis shows that reform shall be carried out in the aspects of establishing features of the higher vocational and technical education colleges, enhancing cooperation between colleges and enterprises, and enhancing overall consideration by the government.

\section{REFERENCES}

[1] Stephen P. Robbins, Management, Beijing: Renmin University of China press, 1997, 298

[2] Zhen Kaiyu, Vocational Ability and Occupational Certificate, Higher Education Study on Science, 2003 (6): 67-68

[3] Zheng Xiqun, Zu Bin, Zhou Qiang, Reflection on the Cultivation of Vocational Ability for Higher Vocational and Technical Education Colleges' Students, Vocational Technology Education, 2004 (34): 34-35

[4] Yang Junwei, Tan Youguang, Research on the Cultivation of Integrated Vocational Ability for Higher Vocational and Technical Education Colleges' Students, China Science and Technology Information, 2005 (11): 194

[5] Sun Wenxue, Cultivation of Vocational Ability for Higher Vocational and Technical Education Colleges' Students Guided by Employment and Reform of Cultivation Mode, Vocational Technology Education (educational science edition), 2005 (4): 20-22

[6] Wang Xiaojie, Rethinking and Suggestion on Vocational Education in China, Vocational Technology Education, 2005 (15): 27-29

[7] Wang Yanling, Characteristics of Reform with Vocational Courses in Advanced Countries since the 1990s, Vocational Technology Education (educational science edition), 2005 (16): 19-22

[8] Wu Xueping, Dong Xingtao, Locating and Features of the Higher Vocational and Technical Education Colleges in China Based on Division of Colleges, Vocational Technology Education, 2005 (16), 32-35 